\title{
ISOLATION OF ASP TOXIN-PRODUCING NITZSCHIA FROM THAILAND
}

\author{
Romero M.L.J. ${ }^{1, *}$, Lirdwitayaprasit T. ${ }^{2}$, Kotaki Y. ${ }^{3 * *}$, Lundholm N. ${ }^{4}$, Relox J. Jr ${ }^{1}$, \\ Furio E.F. ${ }^{5}$, Terada R. ${ }^{6}$, Yokoyama T. ${ }^{3}$, Kodama M. ${ }^{3}$, Fukuyo Y. ${ }^{7}$ \\ 'BFAR, The Philippines; ${ }^{2}$ Chulalongkorn University, Thailand; ${ }^{3}$ Kitasato University, Japan; \\ ${ }^{4}$ University of Copenhagen, Denmark; ${ }^{5}$ NFRDI, The Philippines; ${ }^{6}$ Kagoshima University, Japan, \\ $;^{7}$ ANESC, The University of Tokyo, Japan \\ e-mail:**kotaki@kitasato-u.ac.jp /*marccdt@yahoo.com
}

\begin{abstract}
Nitzschia navis-varingica is recognized as the major ASP toxin producer other than Pseudo-nitzschia species. Surveys on the distribution and the toxin production of this diatom has been conducted in a few countries in eastern Asia and expanded to Thailand. Eighteen isolates from Thailand showed the positive result for the ASP toxin production is DA and IB, although the ratio of IB was much lower than those of the isolates from southern countries including Okinawa, Japan, the Philippines and Vietnam.
\end{abstract}

Keywords: Nitzschia navis-varingica, ASP, Domoic acid, Isodomoic acid, Pennate diatom

\section{INTRODUCTION}

Pseudo-nitzschia multiseries is well known as the major producer of domoic acid (DA), the causative compound of ASP accident in Canada (Bates et al., 1989; Wright et al., 1989). After this accident, other kinds of Pseudo-nitzschia were screened and found as DA producers, although the level of toxin production differs among species (Kotaki, 2002). However, little is known about the diatoms producing DA in eastern Asia, especially in subtropical and tropical areas. During the survey for DA-producing diatoms in eastern Asia, Nitzschia navis-varingica was first isolated as a new species from a shrimp culture pond in Do Son, Vietnam (Kotaki et al., 2000). DA producing Nitzschia was screened and later isolated from wide but limited several areas of Japan (Tohoku district and Okinawa) and the Philippines (Kotaki et al., 2004). During expanding this screening, some Philippine strains of $N$. navisvaringica were newly isolated and confirmed to produce isodomoic acids A(IA) and B (IB) instead of DA (Kotaki et al., 2005) (Fig.1). Re-observation of the HPLC chromatograms of toxin analyses of the Philippine isolates showed that many isolates produce DA and IB and the isolates from limited areas produce IA and IB. It seemed interesting whether $N$. navis-varingica outside the Philippine produces plural ASP toxins or not. Screening and ASP toxin analysis of $N$. navis-varingica was reperformed primarily in Japan, the Philippines and Vietnam. As a result, it was confirmed that major type of the ASP toxin production is DA-IB (all of the isolates from Japan and Vietnam, almost all the isolates from the Philippines), although the ratio of IB showed locality. The ratio of IB was higher in the southernmost isolates. And the minor type of the ASP toxin type was IA-IB that was limited to the isolates obtained from three areas near Manila Bay in the Philippines (Kotaki et al., in press). Then, the survey was expanded to Thailand where no investigation on this topic has been performed. In the present paper, we preliminary report the isolation of pennate diatoms that produce DA and small amount of IB from Thailand. 

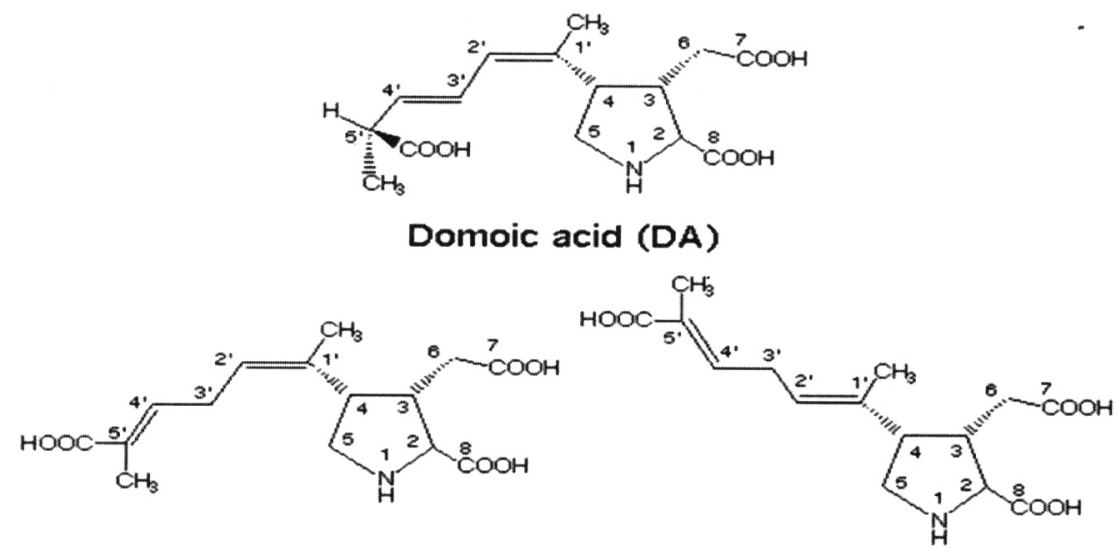

Iso domoic acid A (IA)

Iso domoic acid B (IB)

Figure 1. Structure of domoic acid (DA) and isodomoic acids A (IA) and B (IB)

\section{MATERIALAND METHODS}

\section{Collection and isolation of diatoms}

Collection of Nitzschia-like diatoms were done using scoop net $(20 \mu \mathrm{m})$ at several sites in Chantaburi, Chonburi and Bangkok areas in April 2007. Collected diatoms were inoculated into tissue culture flask filled with $\mathrm{f} / 2$ medium (Guillard, 1983) and incubated for about 10 days at $25^{\circ} \mathrm{C}$ under irradiance level of $70-80 \mu \mathrm{mol}$ photons $/ \mathrm{m} 2 / \mathrm{sec}$ and L:D cycle of 14:10. Unialgal cultures of Nitzschia-like diatoms were established from the crude culture by capillary washing method under light microscope.

\section{Culture of the diatoms}

Established pennate diatom isolates were tested for the ASP production by culture experiment using $50 \mathrm{ml}$ tissue culture tube filled with $30 \mathrm{ml} / 2$ medium. Cell growth was monitored fluorometrically according to the in vivo chlorophyll $a$ fluorescence (Koike et al., 1994).

\section{Toxin analysis}

Production culture was harvested 10 days after it reached the stationary growth phase. Harvested samples were extracted by boiling for three minutes in the test tube (Bajarias et al., 2006). Toxin analysis was done for DA, IA and IB by HPLC with fluorescence detector (Kotaki et al., 1999). Standard of these three toxins were prepared from mass culture of $N$. navis-varingica and from the extract of red alga Chondria armata and calibrated by purchased Canadian standard toxin (DACS 1D) for DA and by weight (IA and IB). Confirmation of IA and IB were done by NMR analyses (Kotaki et al., 2005). ASP toxin content was expressed by pg per cell basis.

\section{Morphlogical observation of the diatoms}

Observation for the species identification was done on the representative strains positive for the ASP toxin production according to Lundholm and Moestrup (2000) and Lundholm et al., (2002).

\section{RESULT AND DISCUSSION}

Twenty Nitzschia-like diatoms were obtained only from six sites near Bangkok, however any Nitzschia-like diatoms were not isolated from Chantaburi and Chonburi at all.

\section{Toxin level and profile of the isolated strains}

As shown in Fig. 2, DA and IB were detected in the HPLC-fluorescence analysis, while IA was not detected. Total ASP toxin contents (DA+IB) of the 18 isolates from 6 sites ranged from 0.3 to 4.3 (average 2.1, DA; 2.0, IB; 0.1 ) pg/cell. Any other DA isomer peak was not observed in the chromatograms analyzed. The ratio of IB against total toxin content ranged from 0 to 25 (average 5 \%) (Fig. 3). In the present paper, Nitzschia-like diatoms isolated from Thailand were newly confirmed to produce DA and IB. Total toxin levels 
of the isolates from Vietnam $(3.1 \mathrm{pg} / \mathrm{cell})$ and Thailand $(2.1 \mathrm{pg} / \mathrm{cell})$ were comparable to those of the Tohoku district ( $1.5 \mathrm{pg} / \mathrm{cell})$ and Okinawa, Japan $(2.1 \mathrm{pg} / \mathrm{cell})$, but lower than that of the Philippines ( $7.3 \mathrm{pg} / \mathrm{cell})$. There was a locality in toxin profile with the tendency that the ratio of IB is higher in southern countries (Kotaki et al. in press). However in the present paper, the ratio of IB of the ASP toxins of Thai isolates is much lower than those of the isolates from southern countries such as Vietnam (35\%), the Philippines (36\%) and Okinawa (28\%) and Japan (Kotaki et al., in press). The average ratio is similar to that of the isolates

1) a)

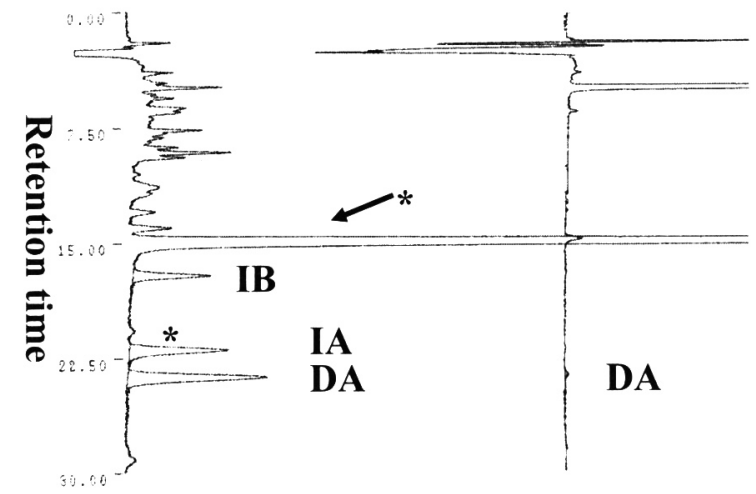

from northern Japan (Tohoku district) (6\%). These tendencies suggest that toxin profile might not be affected by physical factors such as water temperature. One of the axenic strain isolated from the Philipines showed change of the toxin profile from parental non-axenic strain (DA-IB to IAIB) but other two axenic strains did not. These suggest the possibility that ASP toxin profile might be affected by some bacteria or combination of bacteria (Kotaki et al., in press). The effort tracing the bacteria that affect the toxin profile is now under way.
2)

a)

b)

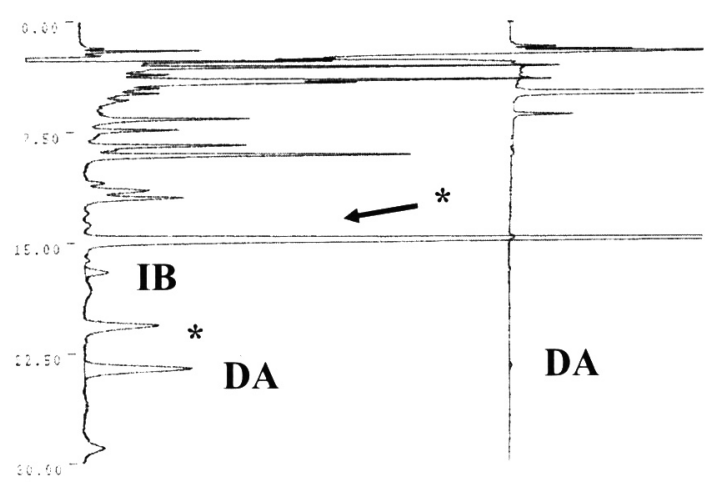

Figure 2. HPLC analysis of the ASP toxins in Nitzschia-like diatom isolated from Thailand.

1) Standard toxins (DAKS 04-1) including domoic acid (DA) and isodomoic acids A (IA) and B (IB)

2) ASP toxins of TMLRA 07-2 strain. a) Analysis with pre-column derivatization of toxins using FMOC$\mathrm{Cl}$ reagent. Fluorescence detection (Ex. $264 \mathrm{~nm}$, Em. $313 \mathrm{~nm}) . b)$ UV detection $(242 \mathrm{~nm})$.

* FMOC-Cl derivatives.

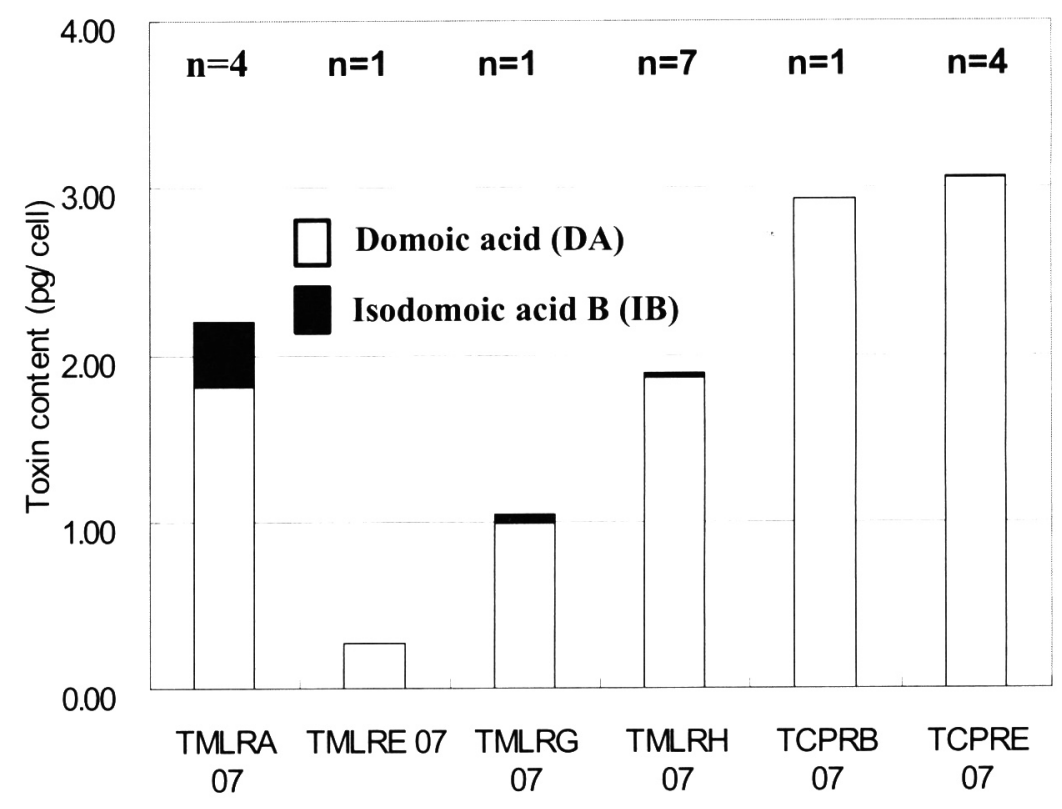

Figure 3. ASP toxin profile of the isolates from Thailand. 


\section{Morphlogical observation of the diatoms}

Morphological characteristics of the toxinproducing diatoms under light microscope was within those of $N$. navis-varingica described by Lundholm and Moestrup (2000). The cells were yellow-brown and possessed two chloroplasts at each end of the cells. Cells were lanceolate in valve view, 38-110 $\mathrm{mm}$ long and 9-11 $\mathrm{mm}$ wide, in girdle view rectangular, slightly indented in the middle. The pervalver axis is wider than the transapical axis. Most cells make ribbon-shaped colonies while growing. Observation under transmission microscope (TEM) is now under way.

Acknowledgement. This work was supported in part by a grant-in-aid for a multilateral cooperative research project (coastal oceanography), from the ministry of Education, Science, Sports and Culture of Japan and by a grant-in-aid for research (C), from the Japan Society for the Promotion of Science (JSPS).

\section{REFERENCES}

Bajarias, F. F. A., Y. Kotaki, J. Relox, Jr., M. L. J. Romero, E. F. Furio, N. Lundholm, K. Koike, Y. Fukuyo, and M. Kodama. 2006. Screening of diatoms producing domoic acid and its derivatives in the Philippines. Coastal Marine Science. 30: 121-129.

Bates, S. S., C. J. Bird, A. S. W. de Freitas, R. Foxall, M. Gilgan, L. A. Hanic, G. R. Johnson, A. W. McCulloch, P. Odense, R. Pocklington, M. A. Quilliam, P. G. Sim, J. S. Smith, D. V. SubbaRao, E. C. D. Todd, J.A. Walter, and J. L. C. Wright. 1989. Pennate diatom Nitzschia pungens as the primary source of domoic acid, a toxin in shellfish from eastern Prince Edward Island, Canada. Can. J. Fish. Aquat. Sci. 46: 12031215.

Guillard, R. R. L. 1983. Culture of phytoplankton for feeding marine invertebrates. In: BergJr, C. J. [Eds] Culture of Marine Invertebrates. Hutchinson Ross Publishing Co., Stroudsberg, PA, pp. 108-132.

Koike, K., T. Ishimaru, and M. Murano. 1994. A simple integrating-fluorometer for monitoring the growth of benthic microalgae. La mer. 32: 45-50.

Kotaki, Y., K. Koike, S. Sato, T. Ogata, Y. Fukuyo, and M. Kodama. 1999. Confirmation of domoic acid production of Pseudo-nitzschia multiseries isolated from Ofunato Bay, Japan. Toxicon. 37: 677682.

Kotaki, Y., K. Koike, M. Yoshida, C. V. Thuoc, N. T. M. Huyen, N.C. Hoi, Y. Fukuyo, and M. Kodama. 2000.
Domoic acid production in Nitzschia sp. (Bacillariophyceae) isolated from a shrimp-culture pond in Do Son, Vietnam. J. Phycol. 36: 1057-1060.

Kotaki, Y. 2002. Production of domoic acid by diverse species of pennate diatoms. Fisheries Science Suppl. 1. 68: 525-528.

Kotaki, Y., N. Lundholm, H. Onodera, K. Kobayashi, F. A. Bajarias, E. F. Furio, M. Iwataki, Y. Fukuyo, and M. Kodama. 2004. Wide distribution of Nitzschia navis-varingica, a new domoic acid-producing benthic diatom found in Vietnam. Fisheries Science. 70: 28-32.

Kotaki, Y., E. F. Furio, M. Satake, N. Lundholm, T. Katayama, K. Koike, V. P. Fulgueras, F. A. Bajarias, Y. Takata, K. Kobayashi, S. Sato, Y. Fukuyo, and M. Kodama. 2005. Production of isodomoic acids $\mathrm{A}$ and $\mathrm{B}$ as major toxin components of a pennate diatom Nitzschia navis-varingica. Toxicon. 46: 946-953.

Kotaki, Y., N. Lundholm, T. Katayama, E. F. Furio, M. L. J. Romero, J. R. Relox, T. Yasumoto, H. Naoki, M. Y. Hirose, T. D. Thann, C. V. Thuoc, N. T. M. Huyen, P. T. Thu, Y. Takata, M. Kodama, and Y. Fukuyo, in press. ASP toxins of pennate diatoms and bacterial effects on the variation in toxin composition. In: Ojvind Moestrup [Eds] Harmful Algae, The Proceeding of 12th International Conference on Harmful Algae.Intergovermental Oceanographic Commission, UNESCO, Copenhagen, Denmark,

Lundholm, N. and O. Moestrup. 2000. Morphology of the marine diatom Nitzschia navis-varingica, sp. nov. (Bacillariophyceae), another producer of the neurotoxin domoic acid. J. Phycol. 36: 1162-1174.

Lundholm, N., G. R. Hasle, G. A. Fryxell, and P. E. Hargraves. 2002. Morphology, phylogeny and taxonomy of species within the Pseudo-nitzschia americana complex (Bascillariophyceae) with the description of two new species, Pseudo-nitzschia brasiliana and Pseudo-nitzschia linea. Phycologia. 41: 480-497.

Wright, J. L. C., R. K. Boyd, A. S. W. deFreitas, M. Falk, R. A. Foxall, W. D. Jamieson, M. V. Laycock, A. W. McCulloch, A. G. McInnes, P. Odense, V. P. Pathak, M.A. Quilliam, M. A. Ragan, P. G. Sim, P. Thibault, J. A. Walter, M. Gilgan, D. J. A. Richard, and D. Dewar. 1989. Identification of domoic acid, a neuroexcitatory amino acid, in toxic mussels from eastern Prince Edward Island. Can. J. Chem. 67: $481-490$. 